\title{
Lineamentos do Direito Civil do Código de Menores.
}

\author{
Walter Moraes \\ Professor Assistente-doutor de Direito Civil \\ da Faculdade de Direito da Universidade de \\ São Paulo.
}

\begin{abstract}
SUMÁRIo: 1. Introdução. 2. Uma concepção de assistência e tutela adequada ao direito do menor. 3. Tutela geral e supletiva do Estado. 4. O estado de abandono. 5. O menor abandonado. 6. Estados especiais de abandono. 7. Disciplina tutelar do menor abandonado: a) Declaração do estado de abandono. 8. b) Inibição. 9. c) Tutela. 10. Disciplina dos estados especiais de abandono. 11. Dois institutos civis peculiares recolhidos no Código de Menores.
\end{abstract}

1 O fato social em razão de que se agrupam as normas civis, penais, trabalhistas, administrativas e processuais que compõem o Código de Menores, é dúplice: abandono e delinquiência. Este o teor do art. $1 .^{\circ}$ que define o campo de incidência do Código a dizer que "o menor, de um ou outro sexo, abandonado ou delinqüiente, que tiver menos de dezoito anos de idade, será submetido pela autoridade competente às medidas de assistência e proteção contidas neste Código" As causas da disciplina legal se distribuem naturalmente: ao direito penal cabe a tutela do menor delinqüente, ${ }^{1}$ ao civil, a do menor abandonado. A demais disciplina que integra o Código tem caráter preventivo e instrumental. De matéria civil se

1. Nisso está, pode dizer-se, o dado especial da parte penal do direito do menor: nāo é sobre a sociedade, contra o infrator, que o direito exerce a sua tutela, senão sobre o Infrator e, até certo ponto, contra a sociedade. 
ocupa cerca da metade deste compêndio de regras. Não só daí, mas sobretudo do aspecto fundamental do problema humano que se situa na sua esfera de ordenação, qual seja o abandono, decorre certa preponderância da matéria civil no direito geral do menor. A própria questão da delinqüência não se desliga de todo da ordem civil, pois a relação existente entre abandono e delinquiência é, via de regra, mas não necessariamente, uma relação de causa para efeito, onde o efeito é a delinqüuência. Tal a razão do interesse que suscita a análise da natureza e do regime jurídico do estado de abandono.

Do ponto de vista do Direito Civil, o problema da proteção do menor abandonado não é, na raiz, diferente do problema da proteção do incapaz em geral.

Partindo do pressuposto, reconhecido como princípio no Direito atual, de que todo homem é sujeito de direito, e considerando que o incapaz, dotado embora de personalidade jurídica, é por definição aquele que não tem aptidão para exercer os seus direitos nem para contrair obrigações, chega-se a este outro postulado de que é absolutamente indispensável (e não meramente convencional) que alguém exerça pelo incapaz os direito dele e bem assim responda pelos seus atos, pois nem é possível que uma pessoa sobreviva se deixar de exercer pelo menos aqueles direitos básicos da vida, nem ainda é cabível que figurem sistematicamente a descoberto da ordem jurídica as lesões a direito provindas de incapazes.

Aí está a summa ratio da questão que se resume na idéia da necessidade de assistência ao incapaz. Comentando o direito belga, a propósito do pátrio poder, Joseph Petit observa que se trata de um direito absoluto à assistência, fundado "na natureza e na razão" 2

2. Petit (Joseph), La Puissance Paternelle, apud L'Etat et l'Enfant. Recueil des Lois et Arrêtés Relatifs a la Protection de l'Enfance Précédés de l'Exposé Historique des Théories Inspiratrices des Diverses Parties de cette Législalation, Pierre van Fleteren Editeur e Arthur Rousseau Editeur, Bruxelas Paris, 1914, pág. 137. 
2 A este conceito de assistência, que não se confunde com o do instituto restritíssimo da assistência devida ao relativamente incapaz (Código Civil, art. 384, v) mas o supera de muito, posto compreenda, além desta, a representação e a proteção jurídica do incapaz (e mesmo do meramente insuficiente) no mais largo sentido ${ }^{3}$, corresponde um conceito de tutela (lato sensu) que também transcende ao do instituito específico dos arts 406 a 445 do Código Civil. Tutela assim concebida é dado incomum na legislação civil pátria mas corrente em outras legislações do sistema românico, conforme adiante se poderá observar; tão pouco a doutrina especializada desconhece a tutela lato sensu ${ }^{4}$

É no direito da família que se concentram os princípios da assistência ao incapaz. O instituto tutelar central é, na verdade, o pátrio poder, que impõe o dever de assistência integral do menor (física, moral, intelectual, econômica e estritamente jurídica: v. CC arts 384-386) A tutela dos arts 406 e sgts do Código Civil é instituição supletiva do pátrio poder (v. arts 422, 424, 426, 427) A curatela (arts 446 e sgts) é, por sua vez, instituição de suprimento da incapacidade da pessoa maior, e o direito alimentar (arts 396 e sgts) complementa as regras da assistência ao incapaz em geral e ao simplesmente insuficiente. Não é demais observar, para que se caracterize o sentido tutelar de todo o direito da família que coloca o incapaz (menor ou maior) como centro e credor de assistência,

3. Cf. a extensão do têrmo, g.v. na L 3200 , art. 15 no $\mathrm{CM}$ arts 19 e 55 , no CC, art. 231, III, no CP arts 244 e sgts.

4. Na doutrina especializada são comuns as locuçōes jurisdição tutelar, tutela integral, espirito tutelar, assistência tutelar, etc. (v. SAJON (RAFAEL), Nuevo Derecho de Menores, Editorial Humanitas, Buenos Aires, 1967, pág. 18, 19, 21, 40). Na doutrina civil pátria tão pouco é raro êste conceito largo de tutela: cf. Bevilaqua (Clovis), Código Civil dos EUB Comentado, 12.a, ed., L. F. Alves, Rio de Janeiro - São Paulo - Belo Horizonte, 1960, II, pág. 279. Pontes (DE) Miranda, Tratado de Direito Privado, 2a ed., Editor Borsói, R. Janeiro, 1956, VII, $§ 759,9$, pág. 171; BARros MONTEIRo (WASHINGTON DE), Curso de Direito Civil, 7.a ed., Saraiva, São Paulo, 1966, II, pág. 4; Ordando Gomes, Direito de Familia, Forense, R. Janeiro - Sāo Paulo, 1968, 218, pág. 347 e sgts.; por seu turno, tanto a doutrina como a legislação especial do trabalho emprega fluentemente tal conceito: v. CLT, T. II e III. 
- que os sistemas de parentesco, filiação (paternidade e maternidade), adoção (simples e plena), interdição e ausência, visam não mais do que estabelecer uma ordem que defina quem sejam os devedores e credores da obrigação tutelar, e que no próprio direito matrimonial podemos ver uma garantia de realização dessa ordem jurídica de assistência ao incapaz. De resto, falhando o mecanismo tutelar do direito da família, quer por falta de seus membros, quer pela omissão e insuficiência dos mesmos, opera então a tutela geral e supletiva do Estado que transparece em todos os passos do Livro I do Código Civil $^{5}$

3. E, essa tutela geral e supletiva do Estado, dado da maior importância para a análise da disciplina do menor abandonado. Conquanto ausente da terminologia técnica da nossa iegislação, merece, pois, particular exame.

Ao que parece, a primeira manifestação de uma consciência jurídica oficial dessa função tutelar do Estado, remonta à época de Justiniano em cujo Codex se denota a existência de orfanotrofos e brefotrofos destinados a receber órfãos e crianças abandonadas. A influência do cristianismo se faz sentir; antes, não há senão raras e esporádicas medidas de caráter assistencial, mas de um modo geral os antigos trataram com rigor e crueldade as crianças sem família ${ }^{6}$

Já a doutrina feudal impunha aos senhores o dever de proteção das crianças abandonadas dentro de seus domínios ${ }^{7}$ No curso da Idade Média é por iniciativa da Igreja que se desenvolve a consciência do dever tutelar social, bem como as instituições de assistência aos incapazes.

Mas é com a Revolução Francêsa que tal consciência se

5. Notadamente nos arts $326, \S \S 1 .^{\circ}$ e $2 .^{\circ}, 327,328,329,386,387,394,403$, $\S$ un., $412,420,421,422,448,454, \S 1 .^{\circ}, 3 . .^{\circ}, 463$.

6. Cf. Gunzburg (Niko), L'Intervention de l'Assistence Publique en Matière de Protection de l'Enfance, apud L'Etat et l'Enfant, op. cit., pág. 225-226.

7. Ibidem. 
consolidou: a Constituinte transferiu para o domínio do Estado todos os bens das corporações e instituições de assistência e tornou objeto de legislação especial o amparo de indigentes, enfermos e crianças; era uma "dívida sagrada", dizia a Declaração dos Direitos do Homem; e das crianças, dispunha o art $1 .^{\circ}$ do Decreto de 28 de junho de 1793 proclamado pela Convenção, "a nação encarrega-se da educação física e moral" daquelas conhecidas sob o nome de "crianças abandonadas" Logo mais, um novo decreto resolveu de chamá-las enfants de la patrie, e a Lei de Pluvioso do ano XIII regulou a "tutela das crianças confiadas aos hospícios. Enfim sobreveio o Decreto Imperial de 19 de janeiro de 1811 que organizou definitivamente a sua proteção, dividindo-as em três categorias: os trouvés (expostos), os abandonnés, os orphilins; a estas categorias, segundo GunZBuRg, deve juntar-se modernamente uma quarta, a dos moralement abandonnés.

Observa este monografista que, de acordo com o espírito da citada Lei de Pluvioso, ano XIII (4.2.1805), que impunha ao governo o dever de ocupar-se da sorte de tais crianças, criando para elas, em lugar dos pais que jamais conheceram, ou que não tinham, uma paternité sociale incumbida do exercício de todos os direitos e todo o poder paterno natural suprindo-lhes os cuidados, a vigilância e a proteção e organizando destarte la tutelle des enfants confiés aux hospices, - o legislador belga criou hospícios civis e departamentos de beneficência onde o encargo dos incapazes cabe a um "conselho de tutela", tutela essa que não elimina a dos pais legítimos e mesmo naturais ${ }^{8}$ Não é outra a função das "comissões administrativas" do direito francês atual (Lei de 15 de abril de 1943) que exercem sobre o menor em estado de abandono o pátrio poder, dando-se a essa proteção o nome de tutelle ${ }^{9}$ Tais crianças são legalmente chamadas pupilles de l'État. Pouco antes, criara-se em França o "conselho de tute-

8. Op. cit., pág. 227-236.

9. Planiol (Marcel), Traité klémentaire de Droit Civil, 4a ed., R. Pichon Durand-Auzlas, Paris, 1948, I, 2144, pág. 716. 
las" (decreto-lei de 1939) com as mesmas funções do antigo "conselho de família", manifestações evidentes da referida tutela geral e supletiva do Estado ${ }^{\mathbf{1 0}}$

Seguindo, nisso a linha do Código Napoleão (art. 405), e mais explícito, talvez, no que tange à participação tutelar do Estado, o Código Civil alemão inseriu no título da tutela uma "sobretutela" (Obervormundschatf) que segundo ScHERER consiste nisso de não ser possível ceder os poderes da tutela sem o consentimento da autoridade pública ${ }^{11}$ Note-se ainda que no direito alemão a tutela impõe-se tanto para menores como para maiores incapazes ${ }^{12}$

O Código Civil suiço vai além, instituindo um pátrio poder (e por conseguinte uma tutela) que se refere ao menor e também ao maior incapaz. (art. 273) Mas é no capítulo da tutela que está a originalidade da lei suiça, pois o que se institucionalizou ali foi uma tutela lato sensu com predominância da ação superior do Estado (art. 360: "São órgãos da tutela: a autoridade de tutelas, o tutor, o curador") Isso levou EgGer a defini-la como sendo o amparo e a representação da pessoa instituída pelo Estado, bem como a faculdade destes indivíduos que carecem de tal proteção, de submeter-se a ela, quer por sua própria vontade, quer por interesse da família ou da sociedade ${ }^{13}$ "Há no direito da tutela, observa a seguir o comentarista, um caráter contraditório. E salvaguarda para o indivíduo e por isso uma ordem de dispositivos de direito privado sem dúvida. $\mathrm{Na}$ verdade esses dispositivos são em parte uma categoria jurídico-pessoal: os princípios sobre a capacidade de agir do pupilo (arts 410 e sgts) são um com-

10. Planiol, op. cit., I, 2117, pág. 710, 1998 e segts. págs. 678 e sgts.

11. Scherer (W.), Familicnrecht des Bürgerlichen Gesetzbuches fïr das Deutsche Reich, Verlag von Palm \& Enke, Erlagen, 1900, 706, pág. 411.

12. Cf. $\S \S 1773-1908$, sp 1858, sgts e 1905; correspondentemente o Código Civil Austríaco, arts 187-188.

13. EGGER (A.), Das Familienrecht des Schweizerischen Zivilgeset:buches, apud Egger, A., Ofer, H., Escher, Arnold, Reichel, Alex., Kommentar zum Schweizerischen Zivilgesetzbuch. II, Schletess \& Co., Zurigue, 1914, pág. 477, 3. 
plemento dos arts 12 e sgts. Noutra grande parte tem eles caráter jurídico-obrigacional (responsabilidade do tutor, art. 426) Os fins da interdição, a ação protetora e o dever de representação do tutor (arts 368 e sgts, 405 e sgts), conduzem, porém, sistematicamente, o direito da tutela, para o direito da família. Mas a tutela é uma assistência estatal (staatliche Fürsorge) Ao direito público competem os preceitos de organização e procedimento, e os princípios sobre as funções das autoridades tutelares (arts 361 e sgts, 373 e sgts, 379 e sgts, 398, 420 e sgts, 427, 455 e sgts) Entretanto, isso não quer dizer que o direito da tutela se decomponha de acordo com cada um dos sistemas a que pertençam os seus dispositivos isoladamente. Trata-se de um todo uniforme, "um ramo singular do direito administrativo com funções de direito privado" (Dernburg, Clässing)" 14 .

O Código Civil italiano não introduz no direito da tutela a disciplina da assistência pública ao menor (v. arts 400 e sgts) ; mas o art. 402 reza que as instituições de assistência pública exercem os poderes da tutela sobre o menor asilado ou assistido, segundo as regras da tutela (arts 343-389) DEGNI, comparando o sistema do Código com o das leis assistenciais anteriores, de semelhante teor, diz destas últimas: "Com tais providências, como se nota, o Estado se substitui ao poder familiar inexistente ou relaxado, atuando um dos maiores e mais essenciais de seus escopos que é o de assegurar a saúde física e moral da estirpe" ${ }^{15}$ Quanto ao Código, observa: "Mas essas leis tinham um caráter administrativo, e isso não era suficiente para uma adequada e eficaz proteção dos menores de dezoito anos privados de genitores ou abandonados. Impunhase enquadrar aquelas providências no Código Civil, transfor-

14. EgGer, op. cit., pág. 478,3, b.

15. DEGN (Francesco), Il Diritto di Famiglia nel Nuovo Codice Civile Italiano, CEDAM, Pádua, 1943, pág. 462. 
mar a ação assistencial da infância numa verdadeira e autêntica atividade tutelar" 16

Por fim, quanto às moderníssimas leis portuguesas de "proteção e assistência" aos menores ("Organização Tutelar de Menores" (Dl 44288 de 20.4.62) e "Lei Orgânica da Direção-geral dos Serviços Tutelares de Menores" (Dl 44287 de 20.4.62), esta última, legislação administrativa), é de notar que os tribunais e ações que institui, dizem-se "tribunais tutelares", "ações tutelares", e os estabelecimentos, "estabelecimentos tutelares de menores", etc. Lembra Soares dA VEIGA que na legislação portuguesa anterior à vigente, os tribunais de menores eram tutores daqueles sujeitos à sua jurisdição para todos os efeitos, sem excetuar o da sua representação em Juízo ${ }^{17}$

4 Por direito, não é, portanto, cabível que um incapaz permaneça desassistido. $\mathrm{O}$ menor está sob pátrio poder decorrente do direito de filiação ou de adoção; se decai do pátrio poder, cai sob tutela específica até emancipar-se. O maior incapaz, uma vêz interdito, cai sob curatela até que restabeleça a capacidade; isto no nosso sistema legal.

No plano dos fatos, porém, é possível que ocorra uma situação de efetiva desassistência, quer porque o incapaz maior não foi declarado interdito nem lhe foi dado curador de acordo com a lei, quer porque ao menor não foi nomeado tutor, quer ainda porque os deveres do pátrio poder, da tutela e da curatela foram neglicenciados.

Que acontece nessas circunstâncias? Age a tutela do Estado, que é geral e supletiva, sobre todos os incapazes. O menor sem tutor e o maior sem curador caem ipso facto sob a tutela privativa do Estado; o menor ou o maior sob pátrio

17. SoARes DA VeIGA (VASCo), Reforma dos Serviços Tutelares de Menores, Coimbra Editora Limitada, Coimbra, 1967, 20, pág. 37. 
poder, tutela ou curatela omissiva ou negligente, incidem no que se pode chamar de tutela concorrente do Estado, para regularização do seu status, a não ser que o tutor omisso seja o próprio Esado; aí não há concurso mas simples regularização. E o que se cuida de demonstrar adiante.

A tutela do Estado se distribui por vários órgãos da Administração, entre os quais avulta o Ministério Público através de curadores que representam o incapaz em juízo, e os órgãos especiais da assistência social do Estado, tudo sob a supervisão e o controle jurídico do Judiciário.

A distinção que se vem traçando entre a assistência devida ao menor e a devida ao maior incapaz, impõe-se com efeito. Porque na assistência ao menor entra o elemento formação. Rafael Sajón o explica dizendo que quando o protegemos, não se exerce sobre êle só o ato concreto e limitado da proteção, como se faz com o alienado, com o cego, com o surdo-mudo, em cujos casos a proteção vem a ser um fim em si mesma. Com o menor, há sempre outra finalidade: a de convertê-lo em maior capaz ${ }^{18}$; sem embargo, acrescenta, a regulamentação da atividade comunitária não deve converter o menor e sua família em escravos da onipotência do govêrno ${ }^{19}$.

Outra distinção impõe-se quanto ao próprio menor, cuja incapacidade pode ser absoluta e relativa. Ora, o menor com mais de dezesseis anos tem capacidade para praticar os atos da vida civil, que em princípio são válidos. A presença do assistente (em sentido estrito) é antes uma medida de caráter cautelar que uma assistência transitiva direta. E, pois, conseqüente que a assistência devida ao absolutamente incapaz há de ser integral e, por sua natureza, diferente da devida ao relativamente incapaz.

Ocorrendo a situação de fato mencionada, pela qual um

18. R. SAJON, op. cit., n. 4, pág. 45.

19. Idem, pgs. 45-46. 
incapaz se vê privado da assistência a que tem direito, e sendo êle um menor absolutamente incapaz, dizemos que êle cai em estado de abandono.

Em princípio, o estado de abandono é a situação de fato do menor absolutamente incapaz privado de assistência.

A sermos coerentes com esta premissa, deveríamos limitar à idade de 16 (dezesseis) anos o estado de abandono, e por conseguinte a disciplina tutelar dele decorrente, como sucede na lei portuguesa (v. supra, 3)

Entretanto, a lei brasileira, como a maior parte das legislações estrangeiras, o estende até a idade de dezoito anos (art. 1. $\left.{ }^{\circ}\right)$ Muito embora não exista, de direito, uma razão muito grave para isso, não existe também inconveniente em tal extensão de idade; não é o plus de assistência que prejudica, senão o minus. Além do mais, este limite de idade de presumível carência tutelar completa, tornou-se tradicional no direito, o que é relevante dentro de um critério histórico, e sobre representar uma garantia de proteção, coincide com o início da capacidade para o trabalho, para o casamento, para a política, e da imputabilidade criminal; de um ponto de vista físico e ainda pedagógico, coincide mais ou menos com o término da adolescência e o início da vida adulta, e com a idade em que a educação se havia de completar tornando apto o indivíduo para o exercício de uma profissão de nível médio, a cumprir enfim a sua missão na comunidade.

Tudo isso justifica o quantum satis a extensão de incapacidade verificada na lei tutelar. Cumpre, pois, adaptar a noção de estado de abandono antes proposta, aos termos do comum das legislações: situação de fato do menor até a idade de dezoito anos privado da assistência a que faz jús.

Quanto ao incapaz maior, e ao menor entre dezoito e vinte e um anos, seguramente dispensam tutela integral. Mesmo privados da assistência civil regular (tutela e curatela), não se consideram abandonados. Nessa situação, se eventualmente 
necessitarem cie assistência para certos atos, fornece-a o Estado através de seus órgãos apropriados, pois que estes incapazes caíram sob a tutela do Estado.

5 O Código de Menores define situações de abandono no art. 26. Define-as empiricamente enumerando uma longa série de situações dentro das quais o menor se considera abandonado. Conceitualmente é, pois, defeituoso. A relação descritiva de situações de fato, não prevê, de um lado, todas as hipóteses, e de outro, incide em redundâncias e incoerências constatáveis ictu oculo. Comentando o conceito disse OrLando Gomes: "Mais impreciso é o conceito de menor abandonado. Entende-se que tem esta condição, não apenas o que foi abandonado pela mãe, senão, também, o que não tenha sido recolhido por parente. Necessário que que o abandono seja voluntário e material, etc. ${ }^{20}$ No que pesem as explicações do ilustre mestre, o conceito legal continua dos mais confusos, mesmo passado pelo crivo das deduções doutrinárias ${ }^{21} \mathrm{Com}$ efeito, não é facilmente encontradiça uma noção que satisfaça como definição. Entre as poucas que provocam interesse, pode-se alinhar esta de Bernar Medina: "Cada menor tem direito a cuidados necessários para o seu completo bem-estar; os menores desprovidos desses cuidados são os abandonados; o deficit pode ir desde alguma carência parcial, à total. Aqui entrariam aquelas denominações que antes empregávamos: o abandono material, o abandono moral e o abandono misto ou total" 22

O conteúdo do art. 26 do Código de Menores é, em resumo, êste: considera-se menor abandonado o que conta

20. Op. cit. n. 4,173 , pág. 274 .

21. Cf., sobre êste conceito, os Anais da X Semana de Estudos do Problema de Menores, ed.'TJ, S. Paulo, 1971, pág. 62 .

22. Medina (Miguel Bernal), La Protección del Menor. El Menor abandonado o en Peligro. Aspectos Sociológicos Relacionados con el Menor, apud Curso de Especialización de Jueces de Menores, OEA - Instituto Interamericano do Menor - UNICEF, Montevideu, 1971, v. pág. 89. 
menos de dezoito anos e não tem seus pais, tutor ou pessoa encarregada de sua guarda, ou que tendo-os, sejam êles desaparecidos ou desconhecidos, ou que, tendo-os presentes, sejam êles indigentes, enfermos, presos, impossibilitados ou incapazes de cumprirem seus deveres de assistência, entregues à prática de atos contrários à moral e aos bons costumes, cruéis, prepotentes, negligentes, exploradores, condenados por crime contra o assistido ou contra outrem, como co-autor, se praticado pelo assistido, condenado a mais de dois anos de prisão por qualquer crime por sentença irrecorrível; de modo que, em razão do exposto, o menor não tenha habitação certa mesmo eventualmente, nem meios de subsistência, ou viva em estado de vadiagem, libertinagem, mendicidade, ou freqüiente lugares e pessoas moralmente não recomendáveis, ou sofram maus-tratos físicos, castigos imoderados, privações, descuidos de saúde, ou que estejam empregados em ocupações perigosas para a saúde física e moral, ou que se vejam excitados à gatunice, mendicidade e libertinagem.

Aí está. Uma das incongruências é a presunção de abandono do menor cujo pai já foi condenado a mais de dois anos de pena corporal por qualquer crime; mesmo não cumprindo a pena, ou após o seu cumprimento, persiste a presunção. Este dispositivo (art. 26, VIII, a) repete o $\S$ único do art. 394 do Código Civil que, como o caput do artigo (caso de abuso e ruína patrimonial dos bens do filho), determina a suspensão do pátrio poder com intuitos patrimoniais; mas não se percebe alguma situação de abandono propriamente dita.

Não é difícil notar que na enumeração do art. 26 (bem como no conceito simples que daí temos inferido (supra, 4), estão contidas todas as hipóteses do art. 395 do Código Civil, bem como as dos arts 31,32 e 34 do mesmo Código de Menores (que repetem a enumeração do art. 26)

Ordinariamente o devedor direto da assistência ao menor são os pais ou o tutor. No Código de Menores aparece ainda a figura da "pessoa encarregada de sua guarda" (aquela que 
"não sendo pai, mãe, tutor, tem por qualquer título a responsabilidade da vigilância, direção ou educação dele, ou voluntariamente o traz em seu poder ou companhia", art. 27)

Não se trata de uma situação peculiar criada pela lei especial. O Código Civil se refere diversas vezes a esta situação, destacando a guarda do pátrio poder e da tutela sobre o menor. Por exemplo, dado o desquite litigioso, pode o juiz confiar a um terceiro a guarda dos filhos, conquanto subsista o pátrio poder dos pais (art. 326, \$ 2. ${ }^{\circ}$; cf. ainda v.g., arts 329, 383, 412 e arts 15, 16 da L 3200) Pode, portanto, ocorrer que o menor sob pátrio poder ou tutela (do particular ou do Estado) seja confiado à guarda de um terceiro, particular ou instituição adequada. Se esta guarda transcorrer normalmente para o menor, não há falar em estado de abandono. A pessoa encarregada da guarda pode assumi-la tanto por intervenção do responsável legal (pai, mãe, tutor, Estado), como sem a intervenção deles, recolhendo o menor e dandolhe amparo; neste caso, a pessoa deve comunicar o fato a autoridade judiciária ou policial em três dias e a autoridade deve notificar o responsável no mesmo prazo (arts 47 e 48), podendo, dito guarda, mantê-la definitivamente se o responsável legal não reclamar em três meses após a notificação. No primeiro caso, o pai, a mãe ou o tutor que confiou a guarda pode recuperá-la quando queira, menos se ficar provado que se desinteressou do menor; então, a autoridade pode manter a guarda do terceiro, decretando ou não a destituição do pátrio poder, ou da tutela, e nomeando (ou não), tutor, ou guarda, ou ainda restituí-lo ao responsável, sempre de acordo com o interesse do menor (arts 50-52)

6. Além do estado comum de abandono do art. 26, o Código de Menores define a seu modo algumas categorias especiais de menores abandonados, destacando-os do rol desse artigo, onde, entretanto, já estavam incluídas. São elas:

a) A dos infantes expostos: são os menores abandonados até a idade de sete anos (art. 14) 
b) A dos mienores vadios: são os que vagam habitualmente pelas ruas e logradouros sem se dedicarem a ocupação séria e útil, tenham ou não representantes legais responsáveis por si; se o tiverem, e mesmo sendo os menores "refratários a receber instrução", claro está que os responsáveis se revelam incapazes de disciplinar-lhes a vida, a criação, a educação (art. 28)

c) A dos menores mendigos: são os que habitualmente pedem esmolas para si ou para outrem, ou pedem donativos sob pretexto de venda ou oferecimento de objetos; o mais comum é que os pais coloquem os filhos a esmolar para eles (art. 29)

d) A dos menores libertinos: são os que habitualmente se dedicam à prática de atos obcenos e à prostituição; os que, pode dizer-se, vivem vida contrária à moralidade (art. 30)

Observa-se que, o que caracteriza o estado legal de abandono dos vadios, mendigos e libertinos, é a habitualidade do seu comportamento.

7 a) Constatado o estado de abandono, o menor é declarado tal pelo juiz competente. Esta declaração é da maior importância no direito concernente ao menor porque marca o momento cla intervenção direta e eficiente do Estado na sua ordem tutelar. Claro, pois, que este procedimento (entre a apresentação do menor em presumível estado de abandono ou a comunicação deste estado, e a declaração judicial do abandono), tem de ser sumário e breve.

Foi dito que o menor sem tutor cai (porque extra postestatem) imediatamente sob a tutela privativa do Estado e o sob pátrio poder ou tutela omissivos ou negligentes cai sob a tutela concorrente do Estado; este último é o menor propriamente abandonado porque se o Estado propicia desde logo a necessária assistência à criança que perdeu pais ou tutor, ele não pode considerar-se em estado de abandono. Só esta tutela estatal explica, aliás, o poder de a autoridade pública intervir 
em qualquer tempo na ordem familiar do menor e particularmente de recolhê-lo a dispor do seu destino desde que seja apresentado algum em abandono.

Apresentado o menor, ou feita a comunicação, pode o juiz, todavia, deixar de declará-lo abandonado, mesmo que tal situação de fato se constate. O Código de Menores cuida detalhadamente desse procedimento desde o art. 55 até o 67, mas tais regras podem resumir-se a isto: o juiz pode deixar de declarar o abandono se assim entender do interesse do menor (art. 55 , e) Não obstante, pode estabelecer normas e condições aos responsáveis, dispondo enfim como entender: pode devolvê-lo com ou sem condições, retirar aos responsáveis a guarda, entregando-a a terceiro particular ou instituição, sob regime que entender, devolvendo-o posteriormente, etc. Mas é certo que se o estado de abandono não se verifica, deve o juiz devolvêlo aos responsáveis.

Declarado, porém, o abandono do menor in manu, firmase a tutela concorrente do Estado que começa a operar na ordem familiar do abandonado, a regular-lhe o status; e a pri meira medida a tomar é a inibição do pátrio poder ou da tutela.

8. b) Inibição (in + habere) é o mesmo que destituição. O Código Civil, arts 394 e 395, prevê duas modalidades de destituição do pátrio poder: suspensão e perda.

O Código de Menores não inova: enumera no art. 32 as situações de abandono que conduzem à perda do pátrio poder, e no art. 34 as que levam à suspensão. Nas duas relações estão incluídas as causas dos arts 394 e 395 do Código Civil, com acréscimo de outras. $\mathrm{O}$ critério de distribuição de causas que inspirou o legislador não se consegue perceber com nitidez. Pelo grosso, a perda do pátrio poder decorre de causas mais graves que denotam efetivo abandono; a suspensão, de causas mais tênues que revelam perigo de completo abandono. 
Mas o pressuposto para uma e outra modalidade é o abandono declarado judicialmente.

A perda do pátrio poder, diz o art. 33 do Código de Menores, é obrigatória, atinge todos os filhos, abrange todos os direitos que a lei confere ao pai ou à mãe sobre a pessoa e os bens dos filhos; vale por tempo indefinido, em princípio é definitiva, mas depois de decorridos cinco anos do trânsito em julgado da sentença destitutória, podem os pais pretender a reintegração (art. 45).

A suspensão é facultativa (art. 35, 36), quer dizer, pode deixar de ser decretada; pode atingir um, alguns, e todos os filhos, bem como abranger alguns ou todos os direitos sobre a pessoa e os bens dos filhos vitimados; vigora indefinidamente e só depois de decorridos dois anos podem os pais pretender a reintegração (art. 45).

Tanto a perda como a suspensão abrange os poderes do pai e da mãe se viverem juntos, mesmo que só um seja o culpado; se viverem separados, atinge o culpado apenas; se viviam juntos e vieram a separar-se, o cônjuge inocente pode pretender a restituição do pátrio poder (art. 38-39).

A declaração do estado de abandono conduz ainda à destituição ou remoção da tutela stricto sensu, se esta for a situação familiar do menor (art. 55, d). As causas previstas no art. 37 estão todas elas confundidas nas situações comuns de abandono do art. 26.

Decretada judicialmente a perda ou a suspensão do pátrio poder ou a destituição da tutela, o menor cai, pelo menos num momento lbgico, sob a tutela privativa do Estado. Se, porém, o menor declarado não estava sob pátrio poder ou tutela específica, já subordinado portanto à tutela do Estado, firma-se, com a declaração, o caráter exclusivo desta última tutela.

O menor sob guarda de terceiro estará sempre sob pátrio 
poder ou tutela familiar ou estatal; configurando-se, nesta circunstância, o estado de abandono, pode a guarda ser retirada sem qualquer formalidade, por simples despacho (art. 40)

$E$ de notar-se que até esta altura o órgão de jurisdição pode dispor da colocação do menor, conforme lhe parecer conveniente, em proveito do mesmo, quer recolhendo-o em estabelecimento público, quer entregando-o à guarda de terceiro (art. $43, \S 3 .^{\circ}$ ), quer ainda mantendo-o no seio da família (art. 55 e $\$$ )

Mas o Código de Menores dá margem a uma hipótese de inibição sem prévia declaração de abandono, muito embora os pais ou tutores o hajam realmente abandonado. Estado de abandono, e abandono pelos pais, são coisas diferentes. A situação mais comum é aquela em que os pais (ou tutores) largam em mãos de outrem os filhos, e desaparecem, enquanto o terceiro dá assistência à criança. E a hipótese do art. 50. Outra situação é a do menor que foi abandonado pelos responsáveis e imediatamente recolhido por quem o resguarda (art. 47) Numa e noutra hipótese, embora tivesse havido ato de abandono por parte dos responsáveis, não se pode falar em estado de abandono do menor que não se privou de assistência. Então, também aqui existe causa para inibição de pátrio poder e de tutela (v. arts 395, II do Código Civil e arts 32, IV, 48, 51, 52, do Código de Menores) .

9. c) Estabelecida assim a tutela privativa do Estado sobre o menor, passa o órgão jurisdicional a decidir do destino dele.

A relação de direito que se estabelece entre o menor (ou incapaz em geral) e o Estado, é de índole jurídico-familiar; o conteúdo desta relação é a assistência e o devedor desta assistência é o Estado; portanto, as regras que regem a matéria são de ordem pública. Desde que o apoio e o amparo da família não existem mais, pondera GuNZBurg, seja porque a morte levou os pais antes que pudessem completar o seu de- 
ver de educação, seja porque os pais, possuídos da miséria ou da desgraça, muito pouco imbuídos de sentimentos de amor, tenham eles mesmos esquecido o seu dever a ponto de abandonar seus filhos, é a Sociedade que por um sentimento de solidariedade assume os deveres de conduzi-los até o seu estado de capacidade ${ }^{23}$

Para o órgão de jurisdição, as alternativas quanto ao destino do menor são várias. Em princípio pode nomear tutor ao menor ou reservar a si a tutela (ao Estado); neste caso, pode tanto confiá-lo à guarda de um particular como guardálo ele próprio internando-o em estabelecimento público apropriado. Pode ainda dá-lo em adoção ou legitimação adotiva. Dentro das alternativas acima, distinguem-se duas situações: ou o menor é colocado em família (tutor, guarda, adotante) ou é internado em estabelecimento público ou particular.

Na X Semana de Estudos do Problema de Menores, o grupo encarregado do estudo do abandono do menor chegou à conclusão de que a internação não é indicada pois conduz o menor a um processo de inadaptação ao meio ambiente; a ordem de preferência, de resto, é a seguinte: a) permanência do menor na família de origem, com utilização de recursos comunitários de promoção social; b) colocação em lares substitutos, incentivando-se o instituto da adoção; c) criação de instituições que se revistam das características de lar ${ }^{24} \mathrm{O}$ Des. Sylos Cintra, estabelecendo uma das proposições fundamentais a que se houvera chegado nos dez anos de estudo, definiu, entre outras, as seguintes conclusões que parecem mais relevantes: "a) o problema do menor abandonado é, antes de tudo, um problema de família; b) o menor tem direito à vida familiar, ainda que se tenha de recorrer a uma família substituta, recomendando-se, em derradeira solução, o internamento, que é sempre um mal; c) todo internamento, quando necessário, deve ser de tipo aberto, de ambiente res-

23. Op. cit. n. 6, pág. 224.

24. Anais, op. cit., pág. 489 
trito, aproximado da casa da família, de dez a vinte pessoas, para que se trave a segregação que fará do menor cada vez mais, um ser anti-social ${ }^{25 \%}$

Todavia, na vida prática, o que se observa é que a colocação da criança em família substituta é a exceção, quer em caráter de guarda, quer de adoção, legitimação adotiva ou tutela; são casos esparsos entre os muitos milhares que correm, haja vista a natural falta de interesse da generalidade das famílias por esses menores, e de outra parte o baixo padrão econômico do povo; a regra é a internação, e não em estabelecimentos-modelo como se idealiza, mas em estabelecimentos particulares pobres ou públicos superlotados, promíscuos, sem condições, muito mais parecidos com prisões do que com lares.

Na verdade é este o cerne do problema do menor abandonado. Não é um problema jurídico e muito menos judiciário, conforme se nota. E questão administrativa, executiva, que exige a atenção do governo, a consciência e a competência do pessoal especializado dos órgãos da assistência pública. donado:

Vejamos as medidas jurídicas aplicáveis ao menor aban-

1) Nomeação de tutor. E a tutela dativa ou atiliana, conhecida desde o direito romano ${ }^{26}$ Como instituto, é a mesma tutela do art. 406 e sgts do Código Civil, salvo nos dispositivos que forem incoerentes com este código. O Código de Menores prevê cinco situações mas apenas três refogem às regras do Código Civil: 1) o tutor escolhido não é obrigado a aceitar a tutela, mesmo inexistindo parentes (art. 43, § 2. ; v. c.c. art. 415) ; 2) aceita a tutela, o tutor é obrigado a cumprila enquanto não for removido; mas desinteressando-se dela, pode, a critério do juiz (art. 53; v. cc art. 444) lograr a remoção a qualquer tempo sem necessidade de alegar alguma cau-

25. Idem, pág. 29-

26. Inst. 1. $20 \mathrm{D} 26,5$. 
sa justificativa especial; 3) o tutor nomeado pode ser destituído ou substituído em qualquer tempo a critério do juiz (art. 53; v. cc art. 413). O dispositivo do art. 43 que permite nomear um estranho se o parente não for idôneo, identifica-se com o art. 410, III e 413, V, do Código Civil; o do art. 44, que isenta os bens do tutor de hipoteca legal, salvo se o pupilo possuir bens, parece decorrer logicamente da interpretação dos arts 418 a 421 do Código Civil.

2) Reserva da tutela para o Estado. O Estado a exercerá, ou diretamente, internando o menor em seus estabelecimentos até que complete a idade de dezoito anos, ou indiretamente, confiando a terceiro (pessoa física ou instituição particular) a guarda do menor (arts 54,55, b) b) Com efeito pelo art. 49 , pode o juiz entregar o menor a particular, para que fique sob sua guarda ou à soldada, e então não há necessidade de nomeação de tutor, salvo para os fins de exercício de atos da vida civil em que se deva nomear tutor. Se o menor tiver ou vier a adquirir bens, e não lhe for dado tutor civil de modo que êle permaneça sob a tutela estatal direta ou indireta, o Estado é responsável por eventuais prejuízos sofridos na sua fazenda. $\mathrm{O}$ art. 421 atribui ao juiz a responsabilidade pessoal e direta pelo eventual dano. Na verdade, os arts 420421 do Código Civil revelam até que ponto vai a tutela peculiar do Estado, bem como o art. 54 do Código de Menores que reza: "Os menores confiados a particulares, a institutos ou associações, ficam sob a vigilância do Estado, representado pela autoridade competente".

3) Adoção e legitimação adotiva. Pressupõe-se aqui a ocorrência dos requisitos e condições especiais dos estatutos de ambas as instituições. Mas para a legitimação adotiva, a própria declaração de estado de abandono preenche condição básica da parte do adotando.

Quanto aos pais ou tutores responsáveis pelo abandono do menor, pois que violaram o dever de prestar-lhe a assistência devida, uma vez decretada a destituição do pátrio poder 
ou da tutela, aplicam-se-lhes penalidades: a primeira é a obrigação de prestar alimentos, fixados na própria sentença destitutória (Código de Menores, art. 4l); a segunda é a pena pecuniária; a terceira é o processo-crime pelos delitos de abandono em que tenham incorrido (arts 59 a 60).

10. O regime jurídico dos expostos, vadios, mendigos e libertinos não é diverso do prescrito para o menor abandonado em geral.

O Capítulo III do Código de Menores (arts 14-25), deita porém algumas regras relativas ao exposto, que não prejudicam as normas comuns mas limitam-se a regular a situação peculiar desta espécie de abandono. Assim mesmo o interesse que tais normas suscitam é mais de caráter histórico do que real. Daí decorre a inutilidade dessas classificações em categorias; na prática o tratamento jurídico é igual para todos os menores abandonados e obedece ao que já foi apontado. A necessidade de diversificação de tratamento dos expostos, bem como as peculiaridades de tipo pedagógico quanto aos vadios, mendigos e libertinos, ocorrem já no âmbito administrativo.

O que os dispositivos do citado Capítulo III do Código de Menores rege é o procedimento do momento da exposição. A. Delville, num histórico da exposição, demonstra o quanto essa instituição evoluiu desde o direito romano até nossos dias em que existe certa consciência geral do dever de amparar os expostos ${ }^{27}$; pelo contrário, no direito romano a exposição era um direito atribuído ao pater, e quem voluntariamente recolhia o exposto podia fazer dele seu escravo. O pai, observa Henri Velge, podia expor e abandonar sem outras restrições que o seu capricho (jus vitae ac necis); este direito de contestar o filho foi absoluto entre os povos da antigüidade ${ }^{28}$. O primeiro estabelecimento destinado a recolher ex-

27. Delviwe (A.), L'Etat-civil de l'Enfant, apud L'Etat et l'Enfant; op. cit. n. 2, pág. 41 e sgts.

28. VelGE (HENrI), La Vie de l'Enfant, apud L'Etat et l'Enfant, op. ett. n. 2, pág. 15. 
postos foi fundado já no Século VIII (787) em Milão, pelo arcipreste Datteo que instituiu a roda a qual, segundo a expressão poética de Lamartine "é uma engenhosa invenção da caridade cristã, que tem mãos para receber mas não tem olhos para ver nem boca para revelar" ${ }^{29}$

A nossa lei exclui de início o sistema das rodas (art. 15). Ela regula, de un lado; o procedimento de quem encontra um exposto (entrega ou comunicação do achado à autoridade, procedimento dessa autoridade (registro e entrega ao juiz): arts $21,22,25$, II) ; de outro lado o ato do recolhimento nuriaa instituição que dève ter um "registro secreto" que garanta 0 incógnito das pessoas que apresentam o exposto (art. 1520). As medidas variam segundo o apresentante seja um terceiro ou a autoridade (arts $17,1^{8}, \S 2 .{ }^{\circ}, 25, \mathrm{I}$ ), a própria mãe que não é obrigada a fazer-se conhecer (art. 18), ou a expôsição seja anônima (arts 20, 23, 24) Os arts 19 e 25 prescrevem penas pela desobediência das normas postas, particularmente pela violação do segredo.

$\mathrm{O}$ art: 61 do Código de Menores trata do procedimento judiciário quanto aos vadios ou mendigos, e o 62 quanto aos libertinos: estatuto sem interesse em face do que já foi exposto acima $(7, a)$

11 O Código de Menores recolheu, ainda, dois institutos civis que não se prendem necessariamente ao pressuposto: do menor abandonado:

1) O Capítulo II (arts 2-13) regula o contrato de ablactação e de guarda de crianças até a idade de dois anos.

Tais contratos se cumprem sob a vigilância, controle e inspeção dos órgãos de assistência da administração pública. Só esta supervisão e interferência do Estado justifica a presença da matéria no código porque, de resto, o que existe é disciplina obrigacional pura.

29. Of. Gunzbura, op. cit. n. 6, pág. 227 e 231. 
No mais, o contrato de ablactação caiu entre nós em desuso. O de guarda é desusado como forma contratual, embora ocorra frequientemente o fenômeno, que só tem aparecido em juízo em casos em que os pais entregam a criança à guarda, desaparecem e deixam de pagar. Já então o caso é de abandono.

2) O art. 46 trata de uma instituição sui generis que é a delegação de pátrio poder, pela qual o pai, mãe ou tutor podem delegar a outrem (particular ou instítuição privada) os direitos contidos no pátrio poder, sob decisão do juiz do domicílio dos pais ou tutor.

Trata-se de negócio jurídico que exige o consenso das partes e, por lei, ao órgão judiciário nada mais resta a fazer além de examinar a ocorrência deste requisito. Merece, pois, o mesmo reparo feito ao contrato de ablactação e guarda quanto à permanência da instituição no código especial. $\mathrm{O}$ antecedente da lei francesa de 24 de julho de 1889 previa, como pressuposto da delegação de pátrio poder, a incapacidade dos pais ou do tutór, ou o abandono da criança ${ }^{30}$ Claro que sob tal condição, o instituto legal se torna mais significativo no terreno do direito especial dos menores.

30. Planiol, Traité, I, 2136, pág. 714. 